\title{
Effect of cortex inactivation on spontaneous activity of cells in perigeniculate and dorsal lateral geniculate nuclei
}

\author{
Jacek Rogala*, Wioletta J Waleszczyk, Andrzej Wróbel, Daniel K Wójcik \\ From Twenty Second Annual Computational Neuroscience Meeting: CNS*2013 \\ Paris, France. 13-18 July 2013
}

The cortical influence on spontaneous activity of single neurons in the dorsal lateral geniculate (LGN) and perigeniculate (PGN) nuclei were investigated in awake cats by means of reversible cooling of cortical areas 17 and 18 [1]. We analyzed subtle changes of the statistical properties of spike trains. To understand their nature we investigated statistics of firing rate (FR), mean interspike interval (ISI), bursting rate (BR), mean intra-burst inter-spike interval (IBISI), mean number of spikes per burst (SPB) and mean burst duration (BD) $[2,3]$.
These results indicate that recurrent inhibition from PGN may play a homeostatic role in the cortico-thalamic loop by restricting thalamic oscillations within their natural functional range [4]. The buffering role of PGN may explain why the massive, direct cortical projection to LGN neurons induces only small, highly-tuned effects during spontaneous activity.

The BR, FR and IBISI measures of spontaneous activity of PGN cells as a result of cortex cooling increased more than $50 \%$ of their original values and more than

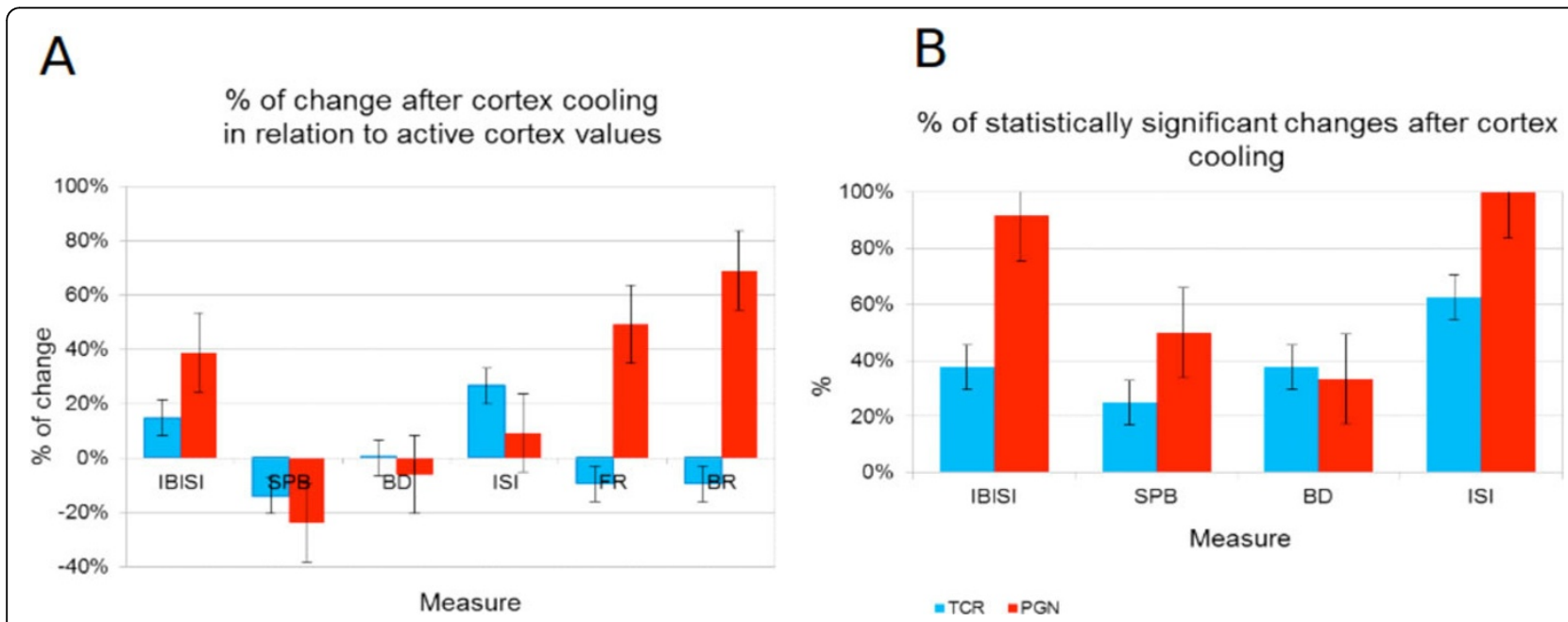

Figure 1 Effect of cortex cooling on activity of PGN and LGN cells. A. Percent of change in relation to situation when the cortex was active. B. Percent of significant differences $(p<0.05)$. IBISI - intra burst ISI, SPB - spikes per burst, BD - burst duration, ISI - mean ISI, FR - firing rate, BR bursting rate.

\footnotetext{
* Correspondence: j.rogala@nencki.gov.pl

Department of Neurophysiology, Nencki Institute of Experimental Biology,

Warszawa, 02-093, Poland
} 
$20 \%$ for SPB while the changes of LGN activity were below $20 \%$ for all measures except ISI, which was the only case where the changes were larger in LGN than in the PGN cells (Figure 1A). The changes of values taken by all the measures used to quantify activity of LGN (except mean ISI) were statistically significant for less than $30 \%$ of investigated neurons, in the case of PGN all the changes except for $\mathrm{BD}$ were significant for more than $40 \%$ of neurons (Figure 1B).

Published: 8 July 2013

\section{References}

1. Waleszczyk WJ, Bekisz M, Wróbel A: Cortical modulation of neuronal activity in the cat's lateral geniculate and perigeniculate nuclei. Experimental Neurology 2005, 196:54-72.

2. Selinger JV, Kulagina NV, O'Shaughnessy TJ, Ma W, Pancrazio JJ: Methods for characterizing interspike intervals and identifying bursts in neuronal activity. Journal of Neuroscience Methods 2007, 162:64-71.

3. Pasquale V, Martinoia S, Chiappalone M: A self-adapting approach for the detection of bursts and network bursts in neuronal cultures. $J$ Comput Neurosci 2010, 29:213-229.

4. Huntsman MM, Porcello DM, Homanics GE, DeLorey TM, Huguenard JR: Reciprocal inhibitory connections and network synchrony in the mammalian thalamus. Science 1999, 283:541-543.

doi:10.1186/1471-2202-14-S1-P418

Cite this article as: Rogala et al:: Effect of cortex inactivation on spontaneous activity of cells in perigeniculate and dorsal lateral geniculate nuclei. BMC Neuroscience 2013 14(Suppl 1):P418.

\section{Submit your next manuscript to BioMed Central} and take full advantage of:

- Convenient online submission

- Thorough peer review

- No space constraints or color figure charges

- Immediate publication on acceptance

- Inclusion in PubMed, CAS, Scopus and Google Scholar

- Research which is freely available for redistribution

Submit your manuscript at www.biomedcentral.com/submit 